TANULMÁNYOK 2019/2. Bölcsészettudományi Kar, Újvidék

STUDIJE 2019/2. Filozofski fakultet, Novi Sad

STUDIES 2019/2. Faculty of Philosophy, Novi Sad

ETO: 821.511.141-2(497.113)

81 '42

378.245

DOI: $10.19090 / \mathrm{tm} .2019 .2 .71-79$

A kézirat leadásának időpontja: 2019. november 19.

Az elfogadás időpontja: 2019. november 24.

TÓTH Anita

Újvidéki Egyetem, Bölcsészettudományi Kar

Nyelv- és Irodalomtudományi Doktori Iskola

Újvidék, Szerbia

anitatot84@gmail.com

\title{
VAJDASÁGI MAGYAR DRÁMÁK DIALÓGUSAINAK SZÖVEGTANI VIZSGÁLATA
}

\section{Tekstološka analiza dijaloga u vojvođanskim mađarskim dramama}

\section{Textological Analysis of Dialogues in Hungarian Dramas in Vojvodina}

Dolgozatom témája a drámai dialógusok szövegtani jellemzőinek a bemutatása. A nyelvi eszközöket funkcionális szempontból közelítjük meg, mellyel azok kommunikatív szerepének a bemutatása a cél. A dolgozat célja, hogy leírja a drámai dialógusok általános jellemzőit, valamint bemutassa azokat a beszélt nyelvi jellemzőket, melyek a tervezett szövegek spontán jellegét eredményezik, a vizsgálat eredményei betekintést engednek azokba a mentális folyamatokba, melyek a szövegek megalkotásához és értelmezéséhez szükségesek.

Kulcsszavak: dráma, drámai dialógusok, kognitív nyelvészet, szövegtan, stílus

Az elemzés a dialógusok külső kapcsolódási tartományához sorolható kontextuális tényezőket (szituációs kontextus, a cselekvés kontextusa, tematikus kontextus) vizsgálja, a párbeszédek szerkezeti jellemzőit (fordulók, szomszédsági párok, témaváltások, szekvenciák), a legalapvetőbb mikroszintű elemek viszonyainak az érvényesülését (deixis, koreferencia), a dráma szerzői utasításait pragmatikai szempontból, a drámai dialógusok indirekt beszédaktusait, a spontaneitás hatását keltő eszközöket, valamint a drámai dialógusokat a stílusrétegzettség szempontjából. 
Az elemzéshez az elméleti keretet a funkcionális (holista) kognitív nyelvészet adja, míg a módszertan felhasználja a funkcionális szemléletű irányzatok (konverzációelemzés, beszédaktus-elmélet) eredményeit is.

A kutatásban szereplő szövegkorpusz öt kortárs drámát foglal magába, melyek a 2010 és 2014 között megrendezésre kerülő Vajdasági Magyar Drámaíró Verseny győztes drámái. Szerbhorváth György: A csizmalehúzó tragédiája - avagy kisvárosi maffiózók (2010), Gyarmati Kata: Üszkös puszta (2011), Danyi Zoltán: Jelentkezzenek a legjobbak (2012), Szabó Palócz Attila: Tudósitás Tündérországból, avagy a mesés történetek ezer árnyalata (aktuállélektani szösszenet) (2013), Bencsik Orsolya: Ki az a Naomi Watts? Kis vaj(d)magyar dráma (2014). Többszereplős társalgásokról van szó, kivéve az utolsó drámát, amely két szereplő párbeszéde. Az életkori megoszlás szerint a drámákban túlsúlyban van a 30-40 és a 40-50 évesek korcsoportja. A nemek aránya a drámák mindegyikében a férfiak felé tolódik el, kivéve az utolsó drámát, ahol két női szereplő párbeszéde zajlik. A szerepek tekintetében találkozunk házastársak, szülők és gyermekek, kollégák, ismerősök, barátok, valamint idegenek közötti beszélgetésekkel. A vizsgált korpusz jellegéből adódóan a foglalkozás és végzettség változója nem releváns.

A dolgozatban minden fejezet megírása négy lépésben történt. Első lépés a vonatkozó szakirodalom feldolgozása, majd a szövegkorpusz tüzetes elemzése a vizsgált jelenségek előfordulási gyakoriságának megállapítása érdekében, ezután a kapott eredmények és a szövegekből vett jellemző példák segítségével a tervezett drámai dialógusok fő jellemzőinek a bemutatása következik, és végül az összegzés.

A dolgozat felépítése: Kognitív nyelvészet, A dialóguskutatás nemzetközi és magyar tudománytörténete, A dráma, A dráma szerzői utasításainak pragmatikai vizsgálata, A vizsgált korpusz szövegtani jellemzői, A drámai dialógusok nézőpont-, valamint tér- és időviszonyainak ábrázolása mikroszintű elemekkel (A deixis, A koreferencia), A vizsgált korpusz dialógusainak jellemzői a társalgáselemzés szempontjából, Kontextuális tényezők (Szituációs kontextus, Cselekvés kontextusa, Tematikus kontextus), A forduló (A fordulók jellemzői, Szomszédsági párok, Betét- és mellékszekvenciák és a közbevetések, Mezoszintű szövegrészek, Beszédaktusok), A dialógus külső és belső szerkesztettségének formai eszközei (Indirekt beszédaktus a dialógusokban), Tervezett drámai dialógusok, A spontaneitás hatását keltő eszközök a tervezett dialógusokban, Stílusvizsgálat, Összegzés.

A kognitív nyelvészet című rész a holista kognitív nyelvészettel foglalkozik részletesen, mivel a dolgozat elméleti keretét ez a szemlélet határozza meg, valamint arra is kitérünk, hogy a kognitív nyelvészet mint elmélet, hogyan tükrözödik a szövegtanban. A nyelv nem véletlenszerüen létrehozott cselekvés, hanem 
a kommunikációs helyzetnek, a hagyomány begyakorlottságának, valamint a kognitív képességeknek és lehetőségeknek a függvénye (Tolcsvai Nagy 1996). Az anyanyelvi beszélő nyelvi tudása összetett tudás, tehát egyszerre strukturális és procedurális, egyszerre holisztikus és morfologikus, univerzális és egyéni. „A holista kognitív irányzat tagadja a nyelv függetlenségét a különböző tudásfajtáktól, és a nyelven belüli önálló, egymástól függetlenül leírható komponenseket, vagyis a nyelv (és az azt modelláló nyelvelmélet) moduláris felépülését. Ez az irányzat a nyelv funkciói közül a kognitív, vagyis a megismerésben betöltött funkciót emeli ki” (Ladányi 2003, 9). A holista kognitív nyelvészet középpontjában a jelentés áll, amelyet a konceptualizációval azonosítanak. A holista kognitív modell a nyelv és a világismeret, valamint a szemantika és a pragmatika összefüggését és elválaszthatatlanságát hangsúlyozza. A kognitív nyelvészet dialógusfelfogása szerint a párbeszéd olyan értelemszerkezeti és szövegszerkezeti forma, melynek résztvevői egymás után, egymást felváltva beszélnek, és az általuk létrehozott fordulók a különböző szinteken ható szövegjellemzők alapján szoros összefüggésben állnak. A forduló határait a beszélő szándéka, a beszédhelyzet, a kontextus és a megelöző vagy követő fordulók szerkezete és tartalma határozzák meg. A fordulók egymással összekapcsolódva szomszédsági párokat alkotnak, és lépésről lépésre alakítják ki a párbeszéd teljes értelemszerkezetét. A párbeszéd egy sajátos struktúrájú és kompozíciójú szövegegység, melynek összetevői kölcsönösen hatnak egymásra a közlő és a befogadó értelemadási folyamataiban (Boronkai 2008, 62). A kognitív nyelvészetre támaszkodva a dialógus olyan értelemszerkezeti és szövegszerkezeti forma, melynek résztvevői egymás után, egymást felváltva beszélnek, és az általuk létrehozott fordulók a különböző szinteken ható szövegjellemzők alapján szoros összefüggést mutatnak. Ez a módszertani és elméleti keret a procedúra fogalmát helyezi előtérbe, vagyis a dialógusok szerkezeti jellemzőit a létrehozás és megértés mentális folyamatainak szemszögéből vizsgálja.

A dialóguskutatás nemzetközi és magyar tudománytörténete címü rész azokkal az elméletekkel foglalkozik (interakciós szociolingvisztika, a beszéd etnográfiája, etnometodológia, konverzációelemzés, beszédaktus-elmélet, interakció-elmélet, diskurzuselemzés), melyek hozzájárultak a dialogikus szövegek vizsgálatához. A holisztikus felfogás a szöveg egészében érvényesíti a pragmatikai szemléletet, és a teljes szövegtől jut el a szöveg egy szükséges összetevőjéig, a megnyilatkozásig, melyet a szövegen belüli és kívüli világ kontextusában vizsgál (Verschueren 1999). Ebben az értelemben az ember nyelvi tevékenysége egyszerre szociokulturális és kognitív tevékenység (Verschueren 1999, 173-175), és a nyelvet az emberi elmék közötti interakciók sorozataként értelmezi (Langacker 1987). A dialógusokban inkább a személyközi kapcsolatok kialakítása és azok fenntartása kerül előtérbe, míg a narratív szövegekben a nyelv megismerö funkciója. 
A dráma címủ rész drámaelmélettel, modern drámaelmélettel és az általunk vizsgált öt dráma elemzésével foglalkozik. „A groteszk a humor formája, sajátos változata. A groteszk alapja mindig valami valós cselekedet, jelenség vagy szándék, amelyet a nagy igyekezet eltorzít, $s$ amely ezáltal - bár a résztvevők azt nem tudják, nem veszik észre, mert elvakultan, egy rögeszmét követve cselekszenek - már-már valótlanná változik. Groteszk lehet egy tett, egy helyzet, egy szereplo"' (Gerold 1988, 179-180). Az általunk vizsgált drámák mindegyikéről elmondható, hogy megjelenik benne a groteszk, a drámákban nincsenek jellemek, a szereplők hétköznapi átlagemberek, akik ábrándoznak, álmodoznak, vágyakoznak. A konfliktusok a szereplők lelkében vannak. Azért vívódnak, mert értelmetlen az életük, nincs céljuk, ezért mindenki szenved. Az örök hétköznapok, az egyhangú élet és banális történések jelennek meg. A drámák szereplőinek a nyelvhasználatára a köznyelv és a szleng, valamint a durva szavak, szószerkezetek használata a jellemző. A magatartásukra pedig általában a bizalmas, családias magatartás a jellemző. Két drámánál figyelhető meg, hogy keretes drámáról van szó. Az egyik Szerbhorváth György A csizmalehúzó tragédiája - avagy kisvárosi maffiózók (2010) címü drámája, melyben az I. felvonás I. jelenete és a II. felvonás V. jelenete adja a keretet. A másik pedig Danyi Zoltán Jelentkezzenek a legjobbak (2012) címü drámája, melyben az I. jelenet és az utolsó, V. jelenet ad keretet a drámának. A drámai dialógus sok elemet átvett a társalgás mint elsődleges, azaz egyszerü beszédmüfaj elemei közül, de nem azonos vele. A drámai dialógus egyik sajátossága a többcsatornás párbeszéd, a több irányba ható értelem, míg a beszélgetés egycsatornás, nem hordoz több értelmet, belső zártság jellemzi. A drámának egyszerre kell cselekvésnek és szövegnek lennie, miközben a drámaiság állandó benne.

A dráma szerzői utasításainak pragmatikai vizsgálata című rész pragmatikai megközelítésből vizsgálja meg azoknak a drámai szövegrészeknek a funkcióját, a jelentésképzésben és a kontextualizációban betöltött szerepét, amelyek nem a dialógusok szövegét alkotják, ilyen a dramatis personae, a hely- és az időjelölés, a dialógusok előtt álló név és a szerzői utasítás. A szerzői utasítások csak akkor jelennek meg a drámában, ha kihatással vannak a dialógusokra. A szerzői utasítások nem leírásként, hanem a drámai dialógus kontextusát, a nyelvi tevékenység körülményeit megjelenítve funkcionálnak, tehát a dráma eseményének a megértéséhez járulnak hozzá.

A drámai dialógusokban vizsgáltuk a deixis szerepét a nézőpont-, valamint a tér- és időviszonyok ábrázolásában, és a következő megállapításokra jutottunk. Az általunk vizsgált drámai dialógusokban az exoforikus deixisek vannak túlsúlyban, és ezen elemek elöfordulásának gyakorisága hozzájárul ahhoz, hogy a fiktív szépirodalmi szöveg a hétköznapi társalgásokra jellemző nyelvhasználatot 
tükrözze, és így magán hordozza a spontán társalgások szövegtipológiai jellemzőit is. Ami a deixis szerepét illeti a nézőpont jelölésében, megállapítható, hogy a tudatosság szubjektumának az áthelyezése jellemzi a drámai müvek beágyazott dialógusait, valamint megjelenik a perspektivizáció is, és gyakran találkozunk a függő beszéd alkalmazásával. Ami a koreferenciát illeti, az általunk vizsgált drámai dialógusokban az anaforikus és a kataforikus koreferencia közül az anaforikus koreferencia van túlsúlyban. A nézőpontviszonyok folyamatos változása a kiindulópontok eltérésével mutat szoros összefüggést. A drámai dialógusokon végzett vizsgálat eredményei alapján a névmási koreferencia kiemelkedő szerepet tölt be a szövegek topik- és fókuszviszonyainak a meghatározásában. A koreferencia és a deixis szorosan összekapcsolódik a drámai dialógusokban. Ez azért lehetséges, mert ezekben a szövegekben a megelőző és a következő említésben vagy a szerzői utasításban célszerü megadni az utalás antecedensét vagy posztcedensét az értelmezési nehézségek elkerülése érdekében.

A kontextuális tényezőket vizsgálva megállapítható, hogy a drámai dialógusokra az összetett tér- és időszerkezet megjelenése a jellemzö, azonban a drámák beágyazott és valós résztvevői nem mindig ugyanabban a térben és időben helyezkednek el. A nyelvi cselekvések más nem nyelvi cselekvésekkel együtt bontakoznak ki. A drámákban a cselekvés kontextusa a szerzői utasításokból következtethető ki. A drámai szövegekben a nem asszociatív témaváltás a leggyakoribb. A visszatérő téma különböző változatainak a megjelenése, valamint az implicit jelentéselemekből transzformált témaváltás is jellemző az általunk vizsgált drámai dialógusokra. A megnyilatkozások létrehozásakor és értelmezésekor müködésbe lép a résztvevők előzetes tudása.

A drámák fordulóinak szerkezeti jellemzőit vizsgálva megállapítható, hogy egy- és kétfokú dialógusok fordulnak elő gyakrabban, ami pedig a dialógusok nyitottságát és zártságát illeti, a zárt dialógustípusok vannak túlsúlyban. A szomszédsági párok közül a kérdés-válasz szomszédsági pár megjelenése a leggyakoribb. A kiegészítendő kérdések aránya pedig nagyobb, mint az eldöntendő kérdéseké. A betét- és mellékszekvenciák és a közbevetések vizsgálatáról elmondható, hogy a közbevetések előfordulásának aránya nagy, fő funkciója a minőségi maxima enyhítése és erősítése prepozicionális és interpozicionális helyzetben.

A mezoszintű szövegrészek címü részről elmondható, hogy a mezoszintü szövegrészt egy kiemelkedő, fókuszban álló téma határozza meg, mely gyakran kifejtett, de kifejtetlen formában is megjelenhet. A vizsgált szövegrészek nézőpont, valamint tér- és időviszonyai gyakran változnak. A társalgások szövegrészei általában kapcsolódnak az előző és a követő fordulókhoz, de előfordul olyan eset is, hogy nem. 
A beszédaktus-elmélet egyes képviselői szerint a beszédaktusok befolyásolják a párbeszédek szerkezetét is (Franke 1990). Tipikus kezdeményező aktusok a kérdés, a kérés, a vélekedés és a javaslat, tipikus reagáló aktusok a beleegyezés, az ígéret, a megtagadás és az elutasítás. Direkt és indirekt aktusokat különböztet meg a beszédaktus-elmélet, így a nyitó fordulónak közvetlen vagy közvetett módon lehet elvárása a válaszfordulóval szemben. A nyitó szituáció beszédaktusának közvetlen vagy közvetett funkciói alapján három alapvető párbeszédtípust különböztetünk meg: kérdéssel, kéréssel és közléssel induló párbeszédeket. A beszédaktusokat vizsgálva megállapítható, hogy a kérés beszédaktusánál a legközvetlenebb és leggyakoribb akaratnyilvánítási stratégia a direkt kérés. A kérdés beszédaktusával induló dialógusok között legnagyobb arányban a funkciótartó eldöntendő kérdés jelenik meg, de funkcióváltó kérdések is előfordulnak. A kérdő formájú beszédaktusok leggyakrabban sugallt kérést vagy felszólítást hordoznak. Azok a dialógusok, amelyek a közlés beszédaktusával indulnak, leggyakrabban valamilyen új információ közlését szolgálják. A közvetett közléssel induló beszédaktusok beágyazott performatívummal, ható igével, feltételes móddal vagy ezek kombinációjával fejeznek ki felszólítást vagy kérést.

A dialógus külső és belső szerkesztettségének formai eszközei című rész foglalkozik a megszólítás és a figyelemfelkeltés különböző formáival, a köszönéssel, mint felhívó elemmel és a kitéréssel, mint a tematikus koherencia megszakításával, valamint a dialógusokban megjelenő indirekt beszédaktusokkal, ezen belül a felszólítás, a kérés és a tanács indirekt modelljével. A beszéd során a beszélőknek ismerniük kell a megfogalmazás közvetett módjait, az indirekt beszédaktusok szerkesztési és értelmezési szabályait. Ezeket a nem szó szerint értendő nyelvi formákat a kultúrától függő viselkedési, udvariassági normák hozzák létre. A párbeszéd során általában gyakori az indirekt beszédaktus, vagyis a közvetett tartalomkifejezés, amikor is a szomszédsági párok a használati, pragmatikai funkcióknak megfelelően érvényesülnek.

A spontaneitás hatását keltő eszközök a tervezett dialógusokban című rész azokat a beszélt nyelvi jellemzőket mutatja be (szintaktikai kifejtetlenség, hibák és hibajavítások), melyek a tervezett dialógusokat a spontán szövegekhez hasonlóvá teszik. Arra mutatunk rá, hogy a drámai dialógusokban jelen levő kifejtetlen szerkesztés, valamint a hibák és hibajavítások előzetes és tudatos tervezés eredményeként jelentkeznek a drámákban. A drámai dialógusokban a kontextuális szintaktikai kifejtetlenséget gyakran a párbeszédek közé illesztett paratextuális szerzői utasítások teszik szemantikailag kifejtetté. A hibák nagy része a beszélő bizonytalanságából ered, mint például az ismétlés, a hezitálás és a túl hosszú szünet. A spontán jelleg biztosításának érdekében a dráma szövege gyakran felhasználja a különféle hibákat és javítási stratégiáikat. 
A stílusvizsgálat címü részben a stílus szociokulturális rétegzettsége szerint a következő stílusértékeket lehet megkülönböztetni (a magatartás stílusváltozója, a helyzet stílusváltozója, az érték stílusváltozója, az idő stílusváltozója, a hagyományozott, intézményes nyelvváltozatok stílusváltozója). A drámákat a szereplők megnyilatkozásainak a stílusrétegzettsége szempontjából vizsgáltuk. Összefoglalva az általunk vizsgált drámákról megállapítható, hogy a magatartás stílusváltozója szerint legtöbb bizalmas és közömbös stílusú megnyilatkozást találunk bennük, majd ezt követi a durva stílus és csak elvétve találunk példát a választékos stílusra. A helyzet stílusváltozója szerint egyértelműen megállapítható, hogy a szereplők informális stílusban beszélnek, míg a formális stílus csak egy-két helyen jelenik meg. Az érték stílusváltozója alapján legtöbb értékmegvonó és csak kevés közömbös stílusú megnyilatkozást találunk a drámákban. Az idő stílusváltozója mindegyik drámában közömbös, azzal, hogy A csizmalehúzó tragédiája címü drámában a szereplők interakciójában az újszerü stílusra is találunk példát. Ez az újszerüség a szavak szintjén jelenik meg. A technika fejlődése új szavak létrejöttét eredményezte, melyet az idősebb generáció már nem ért. A hagyományozott, intézményes nyelvváltozatok stílusváltozója szerint a szereplők sztenderd és városi népnyelvi stílust használnak szlengszavakkal megtüzdelve, melyek erősítik a szereplők között az összetartozás érzését, és mint közösséget elkülönítik őket a többitől. A szlengszavak használata, mely trágársággal párosul, mindegyik drámára jellemzö.

Az általunk felállított hipotézisek a vizsgálat során teljes mértékben beigazolódtak:

A beszédhelyzet összetevői a kontextuális tényezők tekintetében igen nagy változatosságot mutatnak, és a résztvevők mindannyian az adott beszédhelyzetben érvényes szövegek létrehozására és megértésére törekednek.

A szövegek belső szerkezeti jellemzőit figyelembe véve, a szekvenciális rendezettség azt mutatja, hogy a kérdés - válasz szomszédsági pár aránya a legnagyobb. Jellemzők az egy- vagy kétfokú dialógusok, a közbevetések és a mezoszintű szövegrészek használata, a mellékszekvenciák azonban ritkák.

A deixis kulcsfontosságú szerepet tölt be a tervezett dialógusok nézőpontjának, valamint tér- és időviszonyainak a kialakulásában.

A drámai dialógusok koreferenciaviszonyaira a névmási anafora dominanciája a jellemző, és a nyelvileg kifejtő deixis és a koreferencia szoros kapcsolatban van egymással.

A tervezett drámai szövegekben több olyan jelenség is megfigyelhető, melynek célja az élőbeszéd jellemzőinek utánzása a dráma szereplőinek párbeszédeiben. 


\section{Irodalom}

Boronkai Dóra. 2008. A dialógus szövegtani jellemzöi drámai müvek és beszélt nyelvi társalgások alapján. http://doktori.btk.elte.hu/lingv/boronkaidora/diss.pdf (2018. aug. 13.)

Franke, Wilhelm. 1990. Elementare Dialogstrukturen: Darstellung, Analyse, Diskussion. Tübingen: Niemeye.

Gerold László. 1988. A mai magyar dráma. Újvidék: Tankönyvkiadó Intézet.

Ladányi Mária. 2003. A grammatikalizáció kutatása és a modern nyelvelméletek. http://ladanyi. web.elte.hu/grammvegleges.pdf (2018. jún. 5.)

Langacker, Ronald W. 1987. Foundations of cognitive grammar: Volume I. Theoretical prerequisites. Stanford: Stanford University Press.

Tolcsvai Nagy Gábor. 1996. A magyar nyelv stilisztikája. Budapest: Nemzeti Tankönyvkiadó.

Verschueren, Jef. 1999. Understanding Pragmatics. London-New York-Sydney-Auckland: Arnold.

\section{Források}

Bencsik Orsolya. 2014. Ki az a Naomi Watts?: Kis vaj(d)magyar dráma. Kézirat. Újvidék: Az Újvidéki Színház archívuma.

Danyi Zoltán. 2012. Jelentkezzenek a legjobbak. Kézirat. Újvidék: Az Újvidéki Színház archívuma.

Gyarmati Kata. 2011. Üszkös puszta. Kézirat. Újvidék: Az Újvidéki Színház archívuma.

Szabó Palócz Attila. 2013. Tudósítás Tündérországból, avagy a mesés történetek ezer árnyalata: Aktuállélektani szösszenet. Kézirat. Újvidék: Az Újvidéki Színház archívuma.

Szerbhorváth György. 2010. A csizmalehúzó tragédiája - avagy kisvárosi maffiózók. Kézirat. Újvidék: Az Újvidéki Színház archívuma.

\section{Anita TOT}

\section{TEKSTOLOŠKA ANALIZA DIJALOGA U VOJVOĐANSKIM MAĐARSKIM DRAMAMA}

Rad se bavi prikazom tekstoloških karakteristika dramskih dijaloga. Jezičkim alatima pristupamo sa funkcionalne tačke gledišta, čiji je cilj da pokaže njihovu komunikativnu ulogu. Cilj rada je da se opišu opšte karakteristike dramskih dijaloga kao i karakteristike govornog jezika koje rezultiraju spontanim karakterom datih tekstova. Rezultati studije pružaju uvid u mentalne procese potrebne za stvaranje i tumačenje tekstova.

Ključne reči: drama, dramski dijalozi, kognitivna lingvistika, tekstologija, stil 
Anita TÓTH

\section{TEXTOLOGICAL ANALYSIS OF DIALOGUES IN HUNGARIAN DRAMAS IN VOJVODINA}

The subject of the paper is to present the textological features of dramatic dialogues. Linguistic tools are approached from a functional point of view, which aims to demonstrate their communicative role. The purpose of this study is to describe the general characteristics of dramatic dialogues and the spoken language characteristics that result in the spontaneous nature of the given texts; the results of the study provide insight into the mental processes required to create and interpret texts.

Keywords: drama, dramatic dialogues, cognitive linguistics, textology, style 